\title{
Assessment of Stress among Doctors of Dental Medicine
}

\section{Procjena razine stresa doktora dentalne medicine}

\author{
${ }^{1}$ Department of Periodontology and Oral Medicine, School of Dental Medicine University of Sarajevo \\ Katedra za oralnu medicinu i parodontologiju Stomatološkog fakulteta s klinikama, Sveučilišta u Sarajevu, BiH \\ 2 JU medical school Doboj \\ JU Srednja medicinska škola Doboj, BiH \\ 3 Department of Dental Prosthetics, School of Dental Medicine University of Sarajevo \\ Katedra za protetiku Stomatološkog fakulteta s klinikama, Sveučilište u Sarajevu, BIH \\ ${ }^{4}$ Department of Orthodontics, School of Dental Medicine University of Sarajevo \\ Katedra za ortodonciju Stomatološkog fakulteta s klinikama, Sveučilišta u Sarajevu, BiH
}

\begin{abstract}
Introduction: The workplace can be a source of stress. One of the most stressful professions is the profession of doctor of dental medicine (dentist). Multiple forms of stressors lead to such occupational stress. Objective: The research objective was to examine stress levels among dentists in the 25 to 45 year age group. Materials and Methods: This cross sectional study included 105 doctors of dental medicine throughout Bosnia and Herzegovina, aged between 25 and 45 years. The research was conducted by means of a confidential on-line survey. All participants signed the informed consent, and voluntarily filled out the survey form. The research used the PERCEIVED STRESS SCALE-PSS 10. The statistical analysis used the IBM Statistics SPSS v.21 statistics packages and Microsoft Excel 2010. Descriptive statistics, X2 test, and T-test were also used. Results: Of the total number of respondents, $n=105,66(63 \%)$ of them were female and $39(37 \%)$ male respondents. The mean median value of the score was 23 (Mean $=23.080$ ), as a result of which we can conclude that the respondents in the 25-45 year age population group that participated in this study showed a high level of stress based on the completed questionnaire and the answers received from the respondents. Conclusion: The estimated level of stress has been shown to be high in both genders, with no statistically significant difference between genders.
\end{abstract}

Received: May 29, 2019

Accepted: November 19, 2019

Address for correspondence

Indira Mujic Jahic

University of Sarajevo

School of Dental Medicine

Bolnicka 4a, 71000 Sarajevo

indiramujic@hotmail.com

Tel: 0038733214264

Mob: 0038761775637

Key words

Occupational Stress; Dentists

\section{Introduction}

Stress is a term that denotes a condition of the being or person in which we perceive an existing threat to our own integrity $(1,2)$. Stimuli that cause stress are called stressors. If people are constantly exposed to stressors so that there is no time to recover between them, it leads to chronic stress, which can have a major effect on the body $(2,3)$. An individual reaction to stress is the result of: individual sensitivity, the way difficulties are overcome, the person's overall health condition, external factors and the stressors themselves (2, 4). Reactions to stress can be psychological, behavioural, and physiological (5).

The World Health Organization has declared stress in the workplace as the worldwide health epidemic of the 21 th century $(6,7)$. Every workplace may be at risk for the occurrence of certain diseases, but some occupations are considered to be more stressful, including the occupation of dentistry $(2,8)$. Many factors at work can lead to stress. Some of these are: clinical work, adverse working conditions, work with nervous and anxious patients, work that often causes pain in the patient, time pressures and other limitations, an obligation to continuously work on additional training in or-
Uvod

Stres je pojam koji označava stanje organizma u kojem doživljavamo prijetnju svojem integritetu $(1,2)$. Podražaje koji ga uzrokuju nazivamo stresorima. Ako između stresora ne postoji razdoblje potrebno za oporavak nego se nižu jedan za drugim, pojavljuje se kronični stres koji izaziva ozbiljne zdravstvene posljedice $(2,3)$. Reakcija pojedinaca na stres rezultat je individualne osjetljivosti, načina svladavanja poteškoća, cjelokupnog zdravstvenog stanja, vanjskih utjecaja i stresora $(2,4)$. Reakcije mogu biti psihološke, ponašajne i fiziološke (5).

Svjetska zdravstvena organizacija proglasila je stres na radnome mjestu svjetskom epidemijom $(6,7)$. Svako radno mjesto može biti rizično za pojavu određenih bolesti, ali određena se zanimanja smatraju stresnijima, a među njima i zanimanje doktora dentalne medicine $(2,8)$. Stomatolozima mnogi čimbenici na poslu mogu potaknuti stres. Neki od njih su klinički rad, nepovoljni radni uvjeti, rad s nervoznim i anksioznim pacijentima, rad koji nerijetko pacijentu uzrokuje bol, vremenski pritisak i ograničenja te izloženost promjenama koje nužno nameću kontinuiranu izobrazbu radi što boljeg obavljanja radnih zadataka. To su opći stresori s koji- 
der to allow the dentist to perform his / her own tasks more effectively. These are general factors that represent the main challenges every dentist must face in order to be able to provide their patients with the highest quality healthcare and to show a humane attitude to them, and they are also combined with full and strict compliance with the medical code of ethics $(6,9,10)$. In addition to these stressors, dentists are also exposed to a number of other occupational risks (stressors) in their workplace that are specific to this particular profession. These also include biological risks (the possibility of biological infection), chemical risks (contact with different chemicals), and physical risks (radiation) (8.11). The consequences of dissatisfaction in the workplace are reflected in frequent sick leave, errors at work, professional burnout, job abandonment, reduced satisfaction of the healthcare service recipient, and the reduced quality of mental health in doctors $(12,13,14)$. There is an ever increasing necessity to undertake a comprehensive analysis of the stress levels suffered by dentists during their work, and to determine the stress factors, including an analysis of the effectiveness of different anti-stress or stress management methods, in order to improve their general health and enable them to practice their medical profession more efficiently, while achieving a higher degree of service quality (6).

It is worth noting that at no point is due attention paid to how to deal with stress, not even at first and second year level, during undergraduate, postgraduate and professional education studies, or during courses for continuous training.

This research has been conducted with the aim of screening and examining the levels of stress experienced by doctors of dental medicine in the age group between 25 and 45 years, but also with the aim of making gender-aggregated comparisons with regard to whether a higher level of stress is recorded in female or male doctors of dental medicine. This is the first study of stress levels among dentists in Bosnia and Herzegovina. There are currently no relevant data on total stress in the population.

\section{Materials and methods}

The research included a number of dental doctors throughout Bosnia and Herzegovina. Given the uncertain number of dentists employed in Bosnia and Herzegovina, a sample of 100 respondents was taken to be representative, relying on other studies using the PSS 10 scale as a measuring instrument (15). The study was approved by the Ethics Committee of the School of Dental Medicine in Sarajevo, (No. 02-3-4-203-2/19). All participants signed the informed consent and voluntarily filled out the survey form. The survey involved 105 respondents (66 female dentists or $62.9 \%$ and 39 male dentists or $37.1 \%$ ). The age of the subjects ranged from 25 to 45 years. The research was carried out during the months of January and February 2019. This cross sectional study was conducted using an electronic questionnaire. Together with the survey questionnaires, all respondents signed informed consent for participation in the survey. A total of 235 copies of the survey questionnaires were sent to the respondents. The total number of 117 respondents voluntari- ma se svakodnevno suočavaju svi doktori dentalne medicine dok nastoje svojim pacijentima pružiti najbolju uslugu i pokazati humanost poštujući medicinsku etiku i zakone (6, 9, 10). Uz navedene stresore, stomatolozi su na radnom mjestu izloženi i nizu drugih rizika specifičnih za to zanimanje. To su biološki rizici (mogućnost biološke zaraze), kemijski (doticaj $s$ različitim kemikalijama) i fizikalni (zračenje) $(8,11)$. Posljedice nezadovoljstva na poslu rezultiraju čestim bolovanjima, pogreškama u radu, profesionalnim izgaranjem, napuštanjem posla, smanjenim zadovoljstvom primatelja usluge i lošijom kvalitetom mentalnoga zdravlja liječnika $(12,13,14)$. Prijeko je potrebna sveobuhvatna analiza stresa kod stomatologa tijekom rada i determiniranje stresogenih čimbenika, a treba ispitati i učinkovitost različitih antistresnih metoda kakao bi se poboljšalo njihovo opće zdravlje i postiglo učinkovitije i kvalitetnije obavljanje liječničke profesije (6).

Bitno je istaknuti da se nigdje tijekom edukacije - dodiplomske, poslijediplomske i stručne, ali ni kontinuirane - ne posvećuje pozornost prevladavanju stresa.

Istraživanje je provedeno $s$ namjerom da se ispita razina stresa kod doktora dentalne medicine u dobi između 25 i 45 godina i usporedi je li veća kod žena ili muškaraca. Ovo je prvo istraživanje o stresu kod doktora dentalne medicine u Bosni i Hercegovini. Trenutačno nema relevantnih podataka o ukupnoj zastupljenosti stresa u populaciji.

\section{Materijali i metode}

$\mathrm{U}$ istraživanje su bili uključeni doktori dentalne medicine iz cijele Bosne i Hercegovine. $S$ obzirom na to da se ne zna ukupan broj zaposlenih doktora dentalne u $\mathrm{BiH}$, broj ispitanika od 100 činio se reprezentativnim u odnosu prema drugim studijama čiji su se autori također koristili ljestvicom PSS-10 kao mjernim instrumentom (15). Ovo istraživanje odobrilo je Etičko povjerenstvo Stomatološkog fakulteta u Sarajevu (br 02-3-4-203-2/19). Svi ispitanici dobrovoljno su pristali sudjelovati. U istraživanje je bilo uključeno 105 ispitanika (66 žena ili 62,9 \% i 39 muškaraca ili 37,1 \%). Dob je bila u rasponu od 25 do 45 godina. Istraživanje je provedeno u siječnju i veljači 2019. Prema vrsti istraživanja riječ je o presječnom istraživanju (engl. cross-sectional study). Provedeno je internetskom anketom koju smo slali na e-adrese doktora dentalne medicine. Svi su, uz anketu, dobili i popratno pismo, tj. trebali su potpisati informirani pristanak koji je bio i potvrda o dobrovoljnom sudjelovanju u istraživanju. Ukupno je poslano 235 anketa, a odgovorilo je 117 ispitanika. 
ly agreed to the survey and completed the questionnaire. The inclusion criteria were that the subjects were doctors of dental medicine, and that they were $25-45$ years of age and did not use drugs with effects on the nervous system. All other respondents were excluded by age. Out of that number, 7 respondents were excluded from the research on account of taking medication that affects the nervous system, 3 respondents were disqualified on account of completing the survey questionnaires inadequately, and 2 were disqualified on account of their current age (both respondents were over 45 years of age). Accordingly, the total number of respondents who were ultimately included in the research was 105 .

The tool used was the Perceived Stress Scale PSS 10, which focuses on simplicity, easy access, higher speed and flexibility. The questions in the PSS ask about feelings and thoughts. The survey participants were asked to evaluate their experiences by using a linear 5-point Likert Scale with the following range of evaluation scores used to express their feelings and thoughts with regard to the perceived levels of stress experienced in the workplace: 0-Never, 1-Almost Never, 2-Sometimes, 3-Fairly Often, 4-Very Often. PSS scores are obtained by reversing responses (e.g., $0=4,1=3,2=2,3=1$ and $4=0$ ) to the four positively stated items (items $4,5,7, \&$ 8 ) and then totalling scores across all scale items. A short 4 item scale could be made from questions 2, 4, 5 and 10 of the PSS 10 item scale (reliability, $\alpha=0,85)$ (16).

The Perceived Stress Scale (PSS 10) has been confirmed by representatives of sub populations to measure stress by age group, race, gender and socio-economic status, and it reflects any changes in stress levels that occur over time. Various studies have shown the good discriminatory validity of the research $(17,18)$.

The Statistics IBM SPSS v.21. and Microsoft Excel 2010 packages were used for the purpose of statistical analysis of the research results, whereas descriptive statistics, $\mathrm{X} 2$ test and T-test were used for statistics data processing.

\section{Results}

The response rate to the disseminated on-line survey questionnaires was $49.8 \%$ - 117 dental doctors responded to the total number of 235 questionnaires disseminated. Bearing in mind the fact that 12 respondents were excluded, 105 or $44.7 \%$ of the total number of the disseminated survey questionnaires were included in the survey.

Table 1 shows the gender structure of the respondents. Tables 2 and 3 show the total stress level scores for female and male respondents. Table 4 shows the PSS-10 gender-aggregated comparison of stress levels, where the scores for female and male respondents are presented for each particular question separately.

Out of the total number of respondents of 105 , an analysis of the gender structure of the respondents involved in the assessment of the stress levels in doctors of dental medicine shows a statistically significant difference in relation to the respondents' gender. The Chi-square test was used to examine the gender structure of the dentists. According to the results of $\mathrm{X} 2=6.94(\mathrm{df}=1)$, we concluded that the difference is statisti-
Inkluzioni kriteriji su bili da su ispitanici doktori dentalne medicine, dobi 25-45 godina, i ne koriste nikakve lijekove sa uticajem na nervni sistem. Svi drugi su isključeni po godinama. Od tog broja sedam ih je isključeno jer su uzimali lijekove koji djeluju na živčani sustav, tri ispitanika nisu odgovarajuće popunila anketu, a dva su bila starija od 45 godina. Tako je ukupan broj ispitanika bio 105.

Za istraživanje se primijenila ljestvica percepcije stresa (PERCEIVED STRESS SCALE - PSS 10), a fokusiralo se na jednostavnost, pristup, brzinu i fleksibilnost. Pitanja se odnose na osjećaje i misli. Od sudionika se tražilo da ocijene svoja iskustva na Likertovoj ljestvici od 5 točaka $(0$ - nikad, 1 - gotovo nikad, 2 - katkad, 3 - dosta često, 4 - vrlo često). Ljestvica percepcije stresa boduje se poništavanjem odgovora (npr., $0=4,1=3,2=2,3=1$ i $4=0$ ) na četiri pozitivno navedene stavke (stavke 4, 5, 7, i 8) i zatim zbrajanjem svih stavki na ljestvici. Kratka ljestvica s četirima stavkama može se napraviti iz pitanja 2, 4, $5 \mathrm{i} 10$ (pouzdanost, $\alpha=0,85)(16$ ).

Ljestvicu percepcije stresa (PSS 10) potvrdili su predstavnici populacija za mjerenje stresa prema dobnim grupama, rasi, spolu i socijalno-ekonomskom statusu, a pokazuje promjene stresa tijekom vremena. Studije su pokazale dobru diskriminativnu valjanost $(16,17)$.

Za statističku analizu rezultata korišsten je paket IBM Statistics SPSS v.21. i Microsoft Excel 2010. U postupku statističke obrade upotrijebljena je i deskriptivna statistika te postupci inferencijalne statistike $\mathrm{X}^{2}$ test $\mathrm{i}$ T-test.

\section{Rezultati}

Stopa odgovora bila je 49,8 \% - na ukupno 235 poslanih anketa odgovorilo je 117 doktora dentalne medicine. $S$ obzirom na to da je 12 ispitanika isključeno, od ukupnog broja poslanih anketa 105 ili 44,7\% odgovora uključeno je u istraživanje.

Tablica 1. odnosi se na spolnu strukturu ispitanika. Tablice 2. i 3. pokazuju ukupan skor stresa za žene i muškarce. Tablica 4. komparacija je razine stresa među spolovima PSS10 i u njoj se nalaze skorovi za žene i muškarce posebno za svako pitanje.

Promatrajući spolnu strukturu ispitanika uključenih u procjenu razine stresa kod doktora dentalne medicine, uočena je statistički značajna razlika u odnosu prema spolu. Chisquare test primijenjen je u procjeni spolne strukture ispitanika. Prema rezultatima $\left[\mathrm{X}^{2}=6,94(\mathrm{df}=1)\right]$ pokazala se statistički značajna razlika među spolovima.

$\mathrm{Na}$ svako postavljeno pitanje iz ljestvice percepcije stresa ispitanici su odgovorili bez znatne statističke razlike između muškaraca i žena u dobi od 25 do 45 godina. Prema rezulta- 
Table 1 Respondents' Gender Structure

Tablica 1. Spolna struktura ispitanika

\begin{tabular}{l|l|c|c|c}
\multicolumn{1}{c|}{ Variables $\bullet$ Varijable } & \multicolumn{1}{c|}{ Categories $\bullet$ Kategorije } & $\begin{array}{c}\text { Frequency n (\%) } \\
\text { Frekvencija n (\%) }\end{array}$ & $\begin{array}{c}\text { Valid Percentage (\%) } \\
\text { Postotak (\%) }\end{array}$ & $\begin{array}{c}\text { Cumulative Percentage(\%) } \\
\text { Ukupni postotak (\%) }\end{array}$ \\
\hline Age $\bullet$ Dob & 25-45 years $\bullet 25-45$ godina & $105(100)$ & $100 \%$ & $100 \%$ \\
Gender $\bullet$ Spol & Male $\bullet$ Muški & $39(37,1)$ & $37,1 \%$ & $37,1 \%$ \\
& Female $\bullet$ Ženski & $66(62,9)$ & $62,9 \%$ & $62,9 \%$ \\
Total $\bullet$ Ukupno & & 105 & $100 \%$ & $100 \%$
\end{tabular}

Table 2 Individual Scores for Male and Female Genders

Tablica 2. Pojedinačna statistika za muškarce i žene

\begin{tabular}{ll|c|c|c|c} 
Q & Gender $\bullet$ Dob & N & Mean $\bullet$ Prosjek & $\begin{array}{c}\text { Std. Deviation } \\
\text { St. devijacija }\end{array}$ & $\begin{array}{c}\text { Std. Error Mean } \\
\text { St. pogreška }\end{array}$ \\
\hline Q1-Q10 & Male $\bullet$ Muškarci & 41 & 22,366 & 4,5263 &, 7069 \\
Q1-Q10 & Female $\bullet$ Žene & 71 & 23,493 & 5,4481 &, 6466 \\
\hline
\end{tabular}

Table 3 Total Scores for Male and Female Genders

Tablica 3. Ukupni skor za muškarce i žene

\begin{tabular}{|c|c|c|}
\hline \multicolumn{3}{|l|}{ Statistics $\bullet$ Statistika } \\
\hline \multicolumn{3}{|l|}{ Q } \\
\hline \multirow{2}{*}{$\mathbf{N}$} & Valid & 112 \\
\hline & Missing & 0 \\
\hline Mean & & 23.080 \\
\hline Std. Error of Mean & & .4855 \\
\hline Median & & 24.000 \\
\hline Mode & & 25.0 \\
\hline Std. Deviation & & 5.1380 \\
\hline Variance & & 26.399 \\
\hline Skewness & & .396 \\
\hline Std. Error of Skewness & & .228 \\
\hline Kurtosis & & .535 \\
\hline Std. Error of Kurtosis & & .453 \\
\hline Range & & 28.0 \\
\hline Minimum & & 12.0 \\
\hline Maximum & & 40.0 \\
\hline Sum & & 2585.0 \\
\hline
\end{tabular}

\begin{tabular}{|c|c|c|c|c|c|c|c|}
\hline & & & Descriptive Sta & cs $\bullet$ Deskrip & statistika & & \\
\hline & $\mathrm{N}$ & $\begin{array}{l}\text { Male • } \\
\text { Muškarci }\end{array}$ & Female $\bullet$ Žene & Minimum & Maximum & Mean $\bullet$ Prosjek & St. devijacija \\
\hline Never $\bullet$ Nikad & 2 & 48.0 & 47.0 & 47.0 & 48.0 & 47.500 & 5.7071 \\
\hline $\begin{array}{l}\text { Almost Never • Gotovo } \\
\text { nikad }\end{array}$ & 2 & 90.0 & 140.0 & 90.0 & 140.0 & 115.000 & 35.3553 \\
\hline Sometimes $\bullet$ Katkad & 2 & 167.0 & 286.0 & 167.0 & 286.0 & 226.500 & 84.1457 \\
\hline Fairly Often $\bullet$ Dosta često & 2 & 99.0 & 214.o & 99.0 & 214.0 & 156.500 & 81.3173 \\
\hline Very Often $\bullet$ Vrlo često & 2 & 23.0 & 49.0 & 23.00 & 49.00 & 36.0000 & 18.38478 \\
\hline Valid N (listwise) & 2 & & & & & & \\
\hline
\end{tabular}

cally significant with respect to the gender of the respondents. The respondents provided answers to each and every question in the Perceived Stress Scale without any significant statistical difference between the male and female doctors of dental medicine detected in the 25 to 45 year age group. According to $\mathrm{T}$-test results, where $\mathrm{T}=1.1(\mathrm{p}=0.26)(\mathrm{df}=8)$, we may conclude that the difference were not shown to be statistically significant when the level of stress in male and female dental medicine doctors is concerned. On the basis of these results, tima T-testa $[\mathrm{T}=1,1(\mathrm{p}=0,26)(\mathrm{df}=8)]$ možemo zaključiti da se razlika nije pokazala statistički značajnom kada je riječ o razini stresa kod liječnica i liječnika. Na temelju toga možemo prihvatiti $\mathrm{H} 0$ hipotezu da ne postoji statistički značajna razlika u skoru stresa između doktorica i doktora dentalne medicine u dobi između 25 godina i 45 godina. 
we can accept the $\mathrm{H} 0$ hypothesis indicating that: "There is no statistically significant difference in the stress scores detected in the female doctors of dental medicine compared with the male doctors of dental medicine in the 25 to 45 year age group".

\section{Discussion}

The results of our research show that the average stress score for our respondents - doctors of dental medicine in the average age group of $25-45$ years, was about 23 (Table 3 ), which is higher than the average value of the PSS-10 scale score, where the normal values for the indicated subpopulation are between 13 and 14 (Annex 1). These results suggest that dental medicine is a stressful occupation. There was also an additional objective set in this research, to examine whether there was a difference in the level of stress between the female and male doctors of dental medicine. No statistically significant difference was found in stress levels between the female and male respondents. The stress score in the female respondents was 23.5, while the stress score in the male respondents was 22.4 (Table 2.). A number of other studies have also dealt with this issue.

The Study of Self- Perceived Stress in Relation to Anxiety, Depression and Health-related Quality of Life among Health Professions Students reported high degree of stress in students (18). "High" stress levels were reported in other studies $(19,20)$.

An extensive study conducted by Myers \& Myers in 2004, involving 2441 respondents, reported that dentists were under considerable stress, but no significant difference was identified in stress levels between the genders (21). We need to mention that the stress assessment study mentioned above used the identical PSS-10 questionnaire that we also used in our research. Some stress studies that have examined stress levels among students of dental medicine have obtained some results in gender terms as well, therefore, we can correlate our findings with those obtained by these studies. The most extensive of these studies was the one conducted by Alhajj M.N. et al. in the 2016/2017 academic year, where a group of 18 researchers examined stress levels in 3568 students of dental medicine in 14 countries. Their results show that the stress level perceived in female students was higher

\section{Rasprava}

Rezultati našeg istraživanja pokazuju da je prosječan skor stresa za naše ispitanike prosječne dobi od 25 do 45 godina oko 23 (tablica 3.), što je više u usporedbi s prosječnom vrijednošću skora prema PSS-10 ljestvici, gdje su za navedenu populaciju normalne vrijednosti između 13 i 14 (prilog 1.). Dakle, rezultati pokazuju da je stomatologija stresno zanimanje. U istraživanju smo imali i dodatni cilj - ispitati postoji li razlika u razini stresa između doktorica i doktora dentalne medicine, no nije zabilježena statistički značajna razlika. Skor stresa za žene bio je 23,5, a za muškarce 22,4 (tablica 2.) Istaknimo da su se autori mnogih studija bavili tom temom.

U istraživanju procjene stresa u odnosu prema anksioznosti, depresiji i zdravlju u usporedbi s kvalitetom života studenata zdravstvenih studija, uočena je visoka razina stresa (18). Povećane vrijednosti skora stresa u odnosu prema ljestvici PSS-10 zabilježene su i u drugim studijama $(19,20)$.

U opsežnoj studiji Myersa i Myersa iz 2004. godine, u kojoj je sudjelovao 2441 ispitanik, istaknuto je da su stomatolozi pod velikim stresom, ali nisu uočene velike razlike kad je riječ o spolu (21). Dodajmo da se u toj studiji za procjenu stresa primjenjivao isti upitnik - PSS-10 - kojim smo se i mi koristili u našem istraživanju. Studije u kojima se ispitivao stres studenata dentalne medicine sadržavaju i rezultate $\mathrm{u}$ odnosu prema spolu, tako da naše rezultate možemo donekle usporediti. Najveća takva studija jest ona M. N. Alhajja i suradnika, a rađena je u akademskoj godini 2016./2017. kada je skupina istraživača - njih 18, ispitivala stres kod 3568 studenata dentalne medicine u 14 država. Njihovi rezultati pokazuju da je uočeni stres kod studentica bio veći od onoga koji percipiraju muškarci, osim u području društvenih stresora koji su suprotni (22). Takvi rezultati bili su u skladu s rezultatima u drugim studijama u kojima su autori također ispitivali stres kod studenata dentalne medicine $(23,24,25)$. P. Sing i suradnici (2015.) napisali su pregledni članak o čimbenicima koji dovode do profesionalnog izgaranja te su na osnovi

\begin{tabular}{|c|c|c|c|c|}
\hline \multirow{12}{*}{$\begin{array}{l}\text { Annex } 1 \text { Norm Table for the PSS } 10 \text { item } \\
\text { inventory } \\
\text { Prilog 1. PERCEIVED STRESS SCALE - Norm Table } \\
\text { for the PSS } 10 \text { item inventory }\end{array}$} & Category • Kategorija & $\mathbf{N}$ & Mean • Prosjek & S.D. \\
\hline & $\begin{array}{l}\text { Gender } \bullet \text { Dob } \\
\text { Male } \bullet \text { muškarci }\end{array}$ & 926 & 12.1 & 5.9 \\
\hline & Female $\bullet$ žene & 1406 & 13.7 & 6.6 \\
\hline & $\begin{array}{l}\text { Age } \bullet \text { dob } \\
18-29 \\
\end{array}$ & 645 & 14.2 & 6.2 \\
\hline & $30-44$ & 750 & 13.0 & 6.2 \\
\hline & $45-54$ & 285 & 12.6 & 6.1 \\
\hline & $55-64$ & 282 & 11.9 & 6.9 \\
\hline & $65 \&$ older $\bullet 65$ i stariji & 296 & 12.0 & 6.3 \\
\hline & $\begin{array}{l}\text { Race } \bullet \text { Rasa } \\
\text { white } \bullet \text { Bijelci }\end{array}$ & 1924 & 12.8 & 6.2 \\
\hline & Hispanic $\bullet$ Latinoamerikanci & 98 & 14.0 & 6.9 \\
\hline & black $\bullet$ crnci & 176 & 14.7 & 7.2 \\
\hline & other minority $\bullet$ ostalo & 50 & 14.1 & 5.0 \\
\hline
\end{tabular}


than that perceived in male students, except in the domain of social stressors, that showed quite the opposite trend (22). These results are in line with the results of a number of other studies that also examined stress levels among students of dental medicine $(23,24,25)$. Sing et al. (2015) wrote a scientific review paper dealing with the topic of various factors resulting in professional burnout, and by basing their findings on another 115 studies from the relevant databases, they came to the conclusion that professional burnout is a multifactorial phenomenon that may occur even at an early point of time in a dentist's career. They also highlighted the need to devise a screening program and undertake preventive measures (26). Similar results were also revealed by other groups of authors: Ab-Maurat et al. among Malaysian dentists, and Te Brake et al in their a longitudinal study, among dentists $(27,28)$. According to a series of research conducted by some authors, no significant differences in stress levels were reported between female and male doctors of dental medicine (29, $30,31,32,33$ ), while some other studies have reported that female doctors of dental medicine were found to suffer from higher stress levels than males in the same profession $(34,35)$.

The American Psychological Association (APA) published a survey dealing with the impacts of stress in 2012. The survey included 2020 respondents over the age of 18. It examined the prevailing views among its respondents about the levels and causes of stress, the rate of respondents' participation in various stress management workshops, and the ways in which respondents cope with stress. The highest impact of stress was reported by the respondents in the 18 to 47 year age group. Accordingly, this is the age group of younger and middle-aged respondents who have a great number of important life events ahead of them and a number of important decisions to make in the future, such as the decision to continue with their education, to seek employment, to enter into a marriage relationship, establish a family, etc. All groups of respondents stated that their stress level is way above the level considered to be an ideal level from the point of view of human health. Nevertheless, respondents over the age of 67 are apparently closer to this ideal level, that is otherwise not harmful for human health. However, the younger population group is not differentiated only by the multitude of decisions and stressful events they are exposed to in comparison with the population in the over 67 age group. The younger respondents stated that they are more inclined towards exhibiting some unhealthy forms of behaviour, and expressing anger and nervousness in response to the stress they feel. Also, they do not sleep long enough and do not have sufficient knowledge about stress management compared with the older population groups. A healthy lifestyle is often not within easy reach for those younger than 47, because they often "struggle" with stress by compulsive overeating, excessive alcohol consumption and immoderate cigarette smoking. One of the most common methods of coping with stress, which is more pronounced in the younger age group of respondents, is to go on obsessive-compulsive shopping sprees, while older respondents increasingly resort to practising religion (36).

Female respondents reported a higher level of stress than male respondents. However, both groups exceeded the limits
115 studija iz relevantnih baza podataka zaključili da je profesionalno izgaranje multifaktorijalni fenomen koji se može pojaviti još tijekom rane karijere pa su istaknuli da je potreban program za probir i preventivne mjere (26). Slične rezultate dobili su i drugi autori u svojim studijama - Ab-Maurat i suradnici (malezijski doktori dentalne medicine) i Te Brake sa suradnicima u njihovim longitudinalnim studijama. (27, 28). Prema istraživanjima nekih autora nisu uočene značajne razlike u stresu između doktorica i doktora dentalne medicine (29 - 33), a u neki ističu da su liječnice više pod stresom u odnosu prema muškarcima iste profesije $(34,35)$.

Američka udruge psihologa (APA) objavila je istraživanje o temi stresa 2012. godine. Sudjelovalo je 2020 ispitanika starijih od 18 godina. Analiziralo se mišljenje o razinama i uzrocima stresa, sudjelovanje u radionicama o upravljanju stresom te na koje sve načine svladavaju stres. Najvišu razinu stresa isticali su ispitanici u dobi od 18 do 47 godina. Dakle, osobe u mlađim i srednjim godinama koje pred sobom imaju još mnogo važnih događaja i odluka poput nastavka školovanja, posla, braka, obitelji i slično. Sve skupine ispitanika izjavile su da je njihova razina stresa iznad one koja se smatra idealnom za zdravlje čovjeka. Ipak, ispitanici stariji od 67 godina bliže su toj idealnoj razini koja ne šteti zdravlju. No, mlađa populacija ne razlikuje se samo prema mnoštvu odluka i stresnih događaja kojima su izloženi u odnosu prema populaciji iznad 67 godina - mlađi su izjavljivali da su skloniji nezdravom ponašanju te izražavanju ljutnje i nervoze kao odgovoru na stres koji osjećaju. Također ne spavaju dovoljno i ne znaju dovoljno o upravljanju stresom u usporedbi sa starijom populacijom. Zdrav način života često je nedohvatljiv mlađima od 47 godina, jer se sa stresom bore prejedanjem, alkoholom i pušenjem. Metoda svladavanja stresa koja je izraženija u mlađoj skupini ispitanika jest i kupnja, a stariji se češće okreću vjeri (36).

Žene ističu veću razinu stresa od muškaraca, no obje skupine nalaze se iznad razine koja ne šteti zdravlju. Na ekstremno visokoj razini stresa više je žena, što je neočekivano s obzirom na činjenicu da u prosjeku žive dulje od muškaraca. Vježbanje i slušanje glazbe najččšce su aktivnosti u prevladavanju stresa u oba spola. Žene, u odnosu prema muškarcima, stres prevladavaju koristeći se uglavnom socijalnim metodama poput druženja s obitelji i prijateljima, kupnje i čitanja, ali i prejedanja i to ponajviše nezdravom hranom. Oba spola nisu sklona traženju profesionalne pomoći u svladavanju stresa i njegovih uzroka (36).

Slišković, Burić, Knežević proveli su istraživanje u koje su bila uključena 1892 nastavnika osnovnih škola - 1658 žena, 231 muškarac. Svi su bili u dobi između 23 i 65 godina. Njihovo zadovoljstvo na radnom mjestu mjereno je $s$ pomoću ljestvice Job Satisfaction $(37,38)$. Nakon statističke obrade rezultati pokazuju da svi ispitanici osjećaju povećanu razinu stresa. Žene su definitivno prednjačile u usporedbi s muškarcima, $s$ obzirom na to da se i pretpostavljalo da su više pod stresom, ali su rezultati uzeti u razmatranje sa zadrškom, zato što je statistički signifikantna razlika u broju ispitanica u odnosu prema ispitanicima (38). U radu Komparacija stresa $i$ mentalnog zdravlja kod medicinskih sestara i policijskih službenika, Joško Sindik, Ana Perinić Lewis, Natalija Novokmet, 
of the stress level that is considered not harmful to health. Exposure to an extremely high level of stress was reported more often by female respondents, which was an unexpected development, considering that on average women have longer lifeexpectancy than men. Physical exercise and listening to music are the most common stress-coping activities for both genders. Unlike men, women cope with stress by using a number of social methods, such as socializing with family and friends, shopping, reading books, but also overeating, most commonly by eating unhealthy foods. Neither gender tends to seek any professional help for coping with stress and its causes (36). A. Sliskovic, I. Buric, I. Knezevic conducted research which included 1892 teachers in primary schools, 1658 of which were women and $231 \mathrm{men}$. All the participants were aged between 23 and 65. Their satisfaction in the workplace was measured using the Job Satisfaction Scale $(37,38)$. The results attained after statistical analysis showed that all the participants displayed a greater level of stress in relation to the scale used. Women significantly differed from men, in the sense that they were under more stress, but that result was taken into account with reservations considering the fact that there was a statistically significant difference between the number of male and female participants (38). In their paper 'A comparison of stress and mental strength in nurses and police officers' Sindik et.al. examined and compared stress and mental strength in police officers and medical staff. The goal of the research was to determine the differences in experienced stress and in the aspects of mental strength in the positively selected police officers and medical nurses / medical technicians. The research was conducted on purposeful samples of 75 nurses in Dubrovnik and 63 criminalists in Zagreb. The questionnaires that were applied were the Stress Test and Short Scale of Strength. The analysis of the main components showed the existence of two stress components: exhaustion/lack of control, and difficulties with eating/sleep. Nurses experience more stress in both components, but they have more mental strength in the dedication aspect. The gender differences in both stress components point to greater stress in women, who also show more prominent dedication. The greater level of stress in nurses and in women can be interpreted by the on-average greater stress in medical professions, as well as the stressful dual role of modern women, regardless of their profession (39).

One of the limiting factors that could have influenced the study results is the fact that we had inadequate distribution of the sample, where the total number of female respondents was higher compared with the total number of male respondents. Sixty-six of them were female respondents, and 39 of them male respondents. Furthermore, the respondents' gender and age were the only factors taken into account as the inclusion criteria. We did not take into account information such as, for example, the respondents' years of service, whether the respondents work in private or public practice, whether the doctors of dental medicine are general practitioners or specialists, whether they are just private practice employees or owners of such a practice, or whether they are married or not, which can be a strong recommendation for any further research on this particular subject matter. One of the criteria that could also have been taken into account was whether the
Dubravka Havaš Auguštin ispitali su i usporedili stres i mentalno zdravlje policijskih službenika i medicinskog osoblja. Svrha istraživanja bila je da se ustanove razlike u izloženosti stresu i utjecaj samoga sebe na mentalno zdravlje kod policijskih službenika i medicinskih sestara/tehničara. Istraživanje je provedeno na uzorku od 75 medicinskih sestara u Dubrovniku i 63 kriminalista u Zagrebu. Upitnik koji je korišten bio je pripremljen prema Stress Testu i Short Scale of Strengthu. Analiza je pokazala dvije glavne komponente stresa - iscrpljenost / gubitak kontrole i poteškoće s jedenjem/spavanjem. Sestre pokazuju višu razinu stresa u svim komponentama, ali imaju bolju mentalnu snagu. Spolne razlike u objema komponentama stresa pokazuju da su žene češće pogođene. Viša razina stresa kod medicinskih sestara i žena može se pripisati iznadprosječnoj izloženosti medicinskih profesija te dvostrukoj ulozi modernih žena, bez obzira na njihovu profesiju (39).

Jedan od limitirajućih čimbenika koji je mogao utjecati na rezultate istraživanja jest $\mathrm{i}$ činjenica da smo imali neadekvatnu distribuciju uzorka - ispitanica je bilo više negoli ispitanika. Od ukupnog broja ispitanika 66 su bile žene, 39 muškarci. Nadalje, kao inkluzijske kriterije uzeli smo samo spol i dob. Nismo uzeli u obzir, npr. godine staža, rad u privatnoj praksi ili državnoj ustanovi, jesu li doktori dentalne medicine općeg smjera ili specijalisti, jesu li samo zaposleni u privatnoj praksi ili su vlasnici ordinacija, jesu li u braku ili ne, što može biti preporuka za daljnja istraživanja. Jedan od kriterija mogao je biti i to bave li se ispitanici nekim hobijem, fizičkom aktivnošću ili nekim drugim oblikom relaksacije te tako svladavaju stresne situacije. Uzimajući u obzir taj čimbenik, moglo bi se raspravljati o učinkovitosti pojedinih terapijskih i preventivnih mjera u borbi protiv stresa.

Sama anketa, kao instrument u istraživanju, može biti pokazatelj rezultata istraživanja kod nekih ispitanika jer je Myers 2000. godine ustanovio da su neki sudionici previše pozitivni u odgovorima na pitanja u takvim vrstama anketa. Nove studije trebale bi biti osmišljene po grupama pojedinaca za koje se čini da su se predstavili u pozitivnom svjetlu. Ipak, potrebno je primijeniti i više tehnika za izbor informacija kako bi se prebrodila razumljiva veza između represivnog suočavanja i nepovoljnog fizičkog zdravlja (40). 
respondents have any kinds of hobbies, whether they practice any regular physical activity or exercise, or some other form of relaxation and thus cope with stressful situations. Taking this factor into account would otherwise enable a more detailed discussion about how effective some therapeutic and preventive stress management measures could be.

As a research tool, this kind of survey itself can be a moderator of research results in some of the respondents, since in his research conducted in 2000, Myers found that some respondents, who possess a repressive coping style, failed to report negative effects, and answer many self-reporting measures in such types of surveys in an overly positive fashion. The new studies should be appointed to the groups of individuals who appear to introduce themselves in a positive light. Nevertheless, it is necessary to use more than one technique for information assortment in order to overcome the better understand link between repressive coping and adverse physical health (40).

\section{Conclusions}

Various kinds of research indicate that the occupation of doctor of dental medicine falls within the category of very stressful professions. Doctors of dental medicine aged 25 to 45 are exposed to various stressors that accompany this profession. Statistical analysis has shown that there is no difference in the level of stress between female and male doctors of dental medicine in the age group of 25 to 45 years.

\section{Conflict of interest}

During the research the authors were not found to be in any kind of conflict of interest.

\section{Zaključak}

$\mathrm{U}$ istraživanjima se navodi da je zanimanje doktora dentalne medicine među najstresnijim profesijama. Doktori dentalne medicine u dobi od 25 do 45 godina izloženi su raznim stresorima koji prate tu profesiju. Statističkom analizom dokazano je da nema razlike u razini stresa kod žena i muškaraca doktora dentalne medicine u dobi između 25 i 45 godina.

\section{Sukob interesa}

Autori nisu bili u sukobu interesa.
Sažetak

Uvod: Svako radno mjesto može biti izvor stresa. Jedno od stresnih zanimanja jest i zanimanje dok tora dentalne medicine. To pokazuju mnogi čimbenici. Svrha: Cilj istraživanja bio je ispitati razinu stresa doktora dentalne medicine u dobi između 25 i 45 godina. Materijal i metode: U ovu presječ nu studiju bilo je uključeno 105 doktora dentalne medicine u dobi od 25 do 45 godina iz cijele Bosne i Hercegovine. Istraživanje je provedeno povjerljivom internetskom anketom. Naravno, svi su ispitanici potpisali informirani pristanak. Za istraživanje je odabran mjerni instrument Ljestvica percepcije stresa (Perceived Stress Scale - PSS 10), a za statističku obradu korišteni su paketi IBM Statistics SPSS v. 21 i Microsoft Excel 2010. Korištena je i deskriptivna statistika te postupci inferencijalne statistike $X^{2}$ test i T-test. Rezultati: Od ukupnog broja ispitanika $(n=105)$, njih $66(63 \%)$ bile su žene i prevladavale su u usporedbi s kolegama kojih je bilo 39 (37\%). Prosječna srednja vrijednost skora iznosila je 23 (Mean =23,080), pa možemo zaključiti da populacija u dobi od 25 do 45 godina koja je sudjelovala u ovom istraživanju pokazuje visoku razinu stresa na temelju odgovora dobivenih na pitanja u upitniku. Zaključak: Procijenjena razina stresa bila je visoka u oba spola, bez statistički značajne razlike između žena i muškaraca.
Zaprimljen: 29. svibnja 2019. Prihvaćen: 19. studenoga 2019

Adresa za dopisivanje Indira Mujić Jahić Sveučilište u Sarajevu Stomatološki fakultet Bolnička 4 a, 71000 Sarajevo, BiH tel: 0038733214264 indiramujic@hotmail.com

Ključne riječi radni stres, doktori dentalne medicine

\section{References}

1. Lumsden DP. Is the concept of "stress" of any use, anymore? In: Randall $\mathrm{D}$ - editor. Contributions to primary intervention in mental health: Working papers. Toronto; 1981.

2. Knezevic B, Milosevic M, Golubic R, Belosevic L, Russo A, Mustajbegovic J. Work-related stress and work ability among Croatian university hospital midwives. Midwifery. 2011 Apr;27(2):146-53.

3. Pejcic N, Jovicic MD, Miljkovic N, Popovic DB, Petrovic V. Posture in dentists: Sitting vs. standing positions during dentistry work--An EMG study. Srp Arh Celok Lek. 2016 Mar-Apr;144(3-4):181-7.

4. McCunney RJ. Psychiatric Aspects of Occupational Medicine. In: McCunney RJ (Ed).A Practical Approach to Occupational and Enviromental Medicine. Boston: Little, Brown and Company; 1994. p. 267-71.
5. Pavicevic L, Bobic J, Stress at work. In: Saric M, Zuskin E- editors. Labor Medicine and the Environment. Medical Publishing: Zagreb; 2002. p. 530-537.

6. Pejcic N, Petrovic V, Dimitrijevic I, Markovic D. Stress caused by work in the dental profession. Stom. 2018 Mar; 24 (1):59-64.

7. National Research Council (NRC), Institute of Medicine IOM.Musculoskeletal Disorders and the Workplace: Low Back Pain and Upper Extremities. Washington, DC; 2001

8. Muhic E, Plancak D, Lajnert V, Muhic A. Predictors of Job Satisfaction in Dental Professionals of the Bosnia and Herzegovina Federation. Acta Stomatol Croat. 2016 Sep;50(3):222-229.

9. Moore R, Brodsgaard I. Dentists' perceived stress and its relation 
to perceptions about anxious patient. Community Dent Oral Epidemiol. 2001 Feb;29(1):73-80.

10. Cooper C, Watts J, Kelly M. Job satisfaction, mental health and job stressors among general dental practitioners in the UK. Br Dent J.1987 Jan;162(2):77-81.

11. MeSH Browser (database on the internet) Health and safety of healthcare staff Bilbao, Spain. European Agency for Safety and Health at Work-Europa; 2013 (cited September 2013). Available from: https://osha.europa.eu/en/sector/healthcare.

12. Michie S, Williams S. Reducing work related psychological ill health and sickness absence: a systematic literature review. Occup Environ Med. 2003 Jan;60(1):3-9.

13. Fothergill A, Edwards D, Burnard P. Stress, bournout, coping and stress management in psychiatrists: findings from a systematic review. Int J Soc Psychiatry. 2004 Mar;50(1):54-65.

14. WestCP, Huschka MM, Novotny PJ et al. Association of perceived medical errors with resident distress and empathy: a prospective longitudinal study. JAMA. 2006 Sep 6;296(9):1071-8.

15. Sivaranjani K S, Balu P, Kumar R S, Muthu J, Devi S S, Priyadharshini V. Correlation of periodontal status with perceived stress scale score and cortisol levels among transgenders in Puducherry and Cuddalore. SRM J Res Dent Sci. 2019;10:61-4.

16. Cronbach L. Coefficient alpha and the internal structure of tests. Psychometrika. 1951;16: 297-334.

17. Cohen S, Williamson G. Perceived stress in a probability sample of the United States. In: Spacapan S, Oskamp S - editors. The Social Psychology of Health: Claremont Symposium on Applied Social Psychology. Newbury Park, CA: Sage;1988. p. 31-67.

18. Racic M, Todorovic R, Ivkovic N, Masic S, Joksimovic B, Kulic M. Self-Perceived Stress in Relation to Anxiety, Depression and Health-related Quality of Life among Health Professions Students: A Cross-sectional Study from Bosnia and Herzegovina. Zdr Varst. 2017 Oct 9;56(4):251-259.

19. Al-Sowygh ZH. Academic distress, perceived stress and coping strategies among dental students in Saudi Arabia. Saudi Dent J. 2013;25(3):97-105.

20. Behzadnia A, Smith DR, Goodson ML. A cross-sectional examination of the relationship between approaches to learning and perceived stress among medical students in Malaysia. Educ Health (Abingdon). 2018 May-Aug;31(2):80-86.

21. Myers and Myers, It's difficult being a dentist: stress and healthin the general dental practitioner. Br Dent J. 2004 Jul;197(2):89-93.

22. Alhajj MN, Khader Y, Murad AH, Celebic A, Halboub E, Márquez JR, et al. Perceived sources of stress amongst dental students. A multicountry study. Eur J Dent Educ. 2018 Nov;22(4):258-271.

23. Crego A, Carrillo-Diaz M, Armfield JM, Romero M. Stress and academic performance in dental students: the role of coping strategies and examination-related self-efficacy. J Dent Educ. 2016 Feb;80(2):165-72.
24. Westerman GH, Grandy TG, Ocanto RA, Erskine CG. Perceived sources of stress in the dental school environment. J Dent Educ. 1993 Mar; $57(3): 225-31$.

25. Al-Saleh SA, Al-Madi EM, Al-Angari NS, Al-Shehri HA, Shukri MM, et al. Survey of perceived stress-inducing problems among dental students, Saudi Arabia. Saudi Dent J. 2010 Apr;22(2):83-88.

26. Singh P, Aulak DS, Mangat S, Aulak MS, Factors contributing to burnout in dentistry: Systematic review. Occup Med (Lond). 2016 Jan;66(1):2731.

27. Ab-Murat N, Mason L, Kadir RA, Yusoff N, et al. Self-perceived mental well-being amongst Malaysian dentists. Int J Occup Saf Ergon. 2018 Jun;24(2):233-239.

28. Te Brake H, Smits N, Wicherts JM, Gorter RC, Hoogstraten J. Burnout development among dentists: a longitudinal study. Eur J Oral Sci. 2008 Dec;116(6):545-551

29. Pouradeli S, Shahravan A, Eskandarizdeh A, Rafie F, Hashemipour MA. Occupational Stress and Coping Behaviorus Among Dentist in Kerman, Iran. Sultan Qaboos Univ Med J. 2016 Aug;16(3):341-346.

30. Al-Zubair NM, Al'-ak'hali MS, Ghandour IA. Stress Among Dentist in Yemen. Saudi J Dent Res. 2015 Jul; 6(2):140-145.

31. Gorter R, Freeman R, Hammen S, Murtomaa H, Blinkhorn A, Humphris G. Psychological stress in undergraduate dental students: fifth year outcomes compared with first year baseline results from five European dental schools. Eur J Dent Educ. 2008 May;12(2):61-68.

32. Gorter R, Freeman R, Hammen S, Murtomaa H, Blinkhorn A, Humphris G. Psychological stress and health in undergraduate dental students: fifth year outcomes compared with first year baseline results from five European dental schools. Eur J Dent Educ. 2008 May;12(2):61-68.

33. Guthrie E, Black D, Bagalkote H, Shaw C, Campbell M, Creed F. Psychological stress and burnout in medical students: a five-year prospective longitudinal study. J R Soc Med.1998 May;91(5):237-243.

34. Rogers C, Malone KM. Stress in Irish Dentist: Developing effective coping strategies. J Ir Dent Assoc. 2009 Dec-2010 Jan;55(6):304-307.

35. Beschoner P, Braun M, Schonfeldt-Lecuona C, Freudenmann RW \& von Wietershein Gender Aspecte bei Artzinnen und Artzen. Bundesgesundheitsblatt-Gesundheitsforschung-Gesundheitsschutz, 2016;59(10):13431350.

36. American Psychological Association (APA). Stress by Generation. Stressinamer: 2012; p. 19-21.

37. Judge TA, Thoresen CJ, Bono JE, Patton GK. The Job Satisfaction-Job Performance Relationship:A Qualitative and Quantitative Review. Psychol Bull. 2001 May;127(3):376-407.

38. Sliskovic A, Buric I, Knezevic I. Job Satisfaction and Burnout in Teachers: The Importance of Perceived Support from Principal and Work Motivation. Soc Resear. 2016;25(3):371-392.

39. Sindik J. Comparison of stress and mental strength with nurses and police officers. Secur. 2014;56(3):213-221.

40. Myers LB. Identifing repressors: A methodological issue for health psychology. J Psyho\& Health. 2007 Dec;15(2):205-214. 